\title{
Effects of the substitution of cow dung by the rumen content on production and chemical composition of
}

\section{maggots}

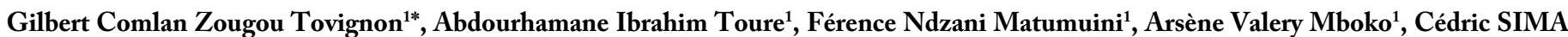 \\ Obiang $^{2}$, Frédéric Christol Ngansop Nono ${ }^{3}$, Kady Divine Moussounda Gassama ${ }^{1}$, Taffarel Juani Mekossangoye Ndounga ${ }^{1}$, Louis Clément \\ Obame Engonga ${ }^{2}$, Joseph-Privat Ondo ${ }^{2}$, Fernand Tendonkeng ${ }^{4}$, Emile Miegoue ${ }^{4}$, Benoit Boukila ${ }^{1}$ and Etienne Pamo Tedonkeng ${ }^{4}$ \\ ${ }^{1}$ National Higher Institute of Agronomy and Biotechnology (INSAB), University of Science and Techniques Masuku (USTM), P.O. Box 941 Franceville, Gabon \\ ${ }^{2}$ Laboratory of Biochemistry, Faculty of Science, University of Science and Techniques Masuku (USTM), P.O. Box 941 Franceville, Gabon \\ ${ }^{3}$ Technical School of Agriculture (TSA) Bambili, P.O. Box 15, Bambili (Bamenda), Cameroon \\ ${ }^{4}$ Laboratory of Animal Nutrition, Department of Animal Sciences, FASA, University of Dschang, P.O. Box 222 Dschang, Cameroon
}

\begin{abstract}
The production of fly larvae for non-ruminants' feeding is an innovative and expanding sector in many countries. An experimental study whose objective was to contribute to improving knowledge in the domain of fly multiplication for maggot production, was conducted at the National Higher Institute of Agronomy and Biotechnology (INSAB) of the University of Science and Techniques, Masuku (USTM) between February and June 2018. The completely randomized experimental design was made up of 4 trials (substrates) of $1,100 \mathrm{~g}$ each, repeated 3 times in plastic basins. The substrates were composed of $\mathrm{S}_{1}(90.91 \%$ of cow dung $+9.09 \%$ of blood), $\mathrm{S}_{2}(68.18 \%$ of cow dung $+22.73 \%$ of rumen content $(\mathrm{RC})+9.09 \%$ of blood $), \mathrm{S}_{3}(45.45 \%$ of cow dung $+45.46 \%$ of $\mathrm{RC}+9.09 \%$ of blood $)$ and $\mathrm{S}_{4}(22.73 \%$ of cow dung $+68.18 \%$ of $\mathrm{RC}+9.09 \%$ of blood). The blood from bovine contained in each mixture served as an attractive material. The results highlighted 04 families of flies: Muscidae (6.35\%), Calliphoridae (85.71\%), Strationomiydae (4.76\%) and Syrphidae (3.17\%). The substrate $\mathrm{S}_{4}$ had the highest fresh and dry biomasses of maggots respectively $20.67 \pm 25.15 \mathrm{~g}$ and $3.67 \pm 4.72 \mathrm{~g}$. The highest length $(1.88 \pm 0.08 \mathrm{~cm})$ was obtained with maggots from the substrate $\mathrm{S}_{1}$. Although this value was significantly higher $(\mathrm{p}<0.05)$ than the length observed with maggots from the substrate $\mathrm{S}_{4}(1.43 \pm 0.24 \mathrm{~cm})$, it was therefore, comparable ( $\left.p>0.05\right)$ to those obtained in substrates $\mathrm{S}_{2}(1.74 \pm 0.13 \mathrm{~cm})$ and $\mathrm{S}_{3}(1.82 \pm 0.06 \mathrm{~cm})$. The highest dry matter $(\mathrm{DM})$ content $(27.61 \pm 21.62 \%)$ was recorded with maggots from $\mathrm{S}_{2}$ while the lowest DM content $(17.25 \pm 2.48 \%)$ was recorded in $\mathrm{S}_{4}$. However, no significant difference $(\mathrm{p}>0.05)$ was observed between the DM in all the substrates. The crude protein (CP) content in maggot flours from $\mathrm{S}_{4}(35.98 \pm 2.21 \%)$ and $\mathrm{S}_{3}(34.66 \pm 0.10 \%)$ was comparable $(\mathrm{p}>0.05)$ and significantly higher $(\mathrm{p}<0.05)$ than in $\mathrm{S}_{2}(27.57 \pm 0.20 \%)$ and in $\mathrm{S}_{1}(26.56 \pm 0.32 \%)$. The highest fat content $(24.87 \pm 0.32 \%)$ was obtained with maggot flour from $\mathrm{S}_{3}$ and the lowest content was found in $\mathrm{S}_{2}(8.91 \pm 0.30 \%)$. At the end of this experimental study, the substrate $\mathrm{S}_{4}(25 \%$ of cow dung and $75 \%$ of RC) could be considered in large scale maggot production for animal feeding.
\end{abstract}

\section{Introduction}

Gabon constantly uses imports to meet its food needs (DGSGabon, 2009) [1]. Also, to reduce its dependence on the external market, livestock production appears as a key sector to develop in order to meet the ever-increasing food demand. Therefore, the development of this sector is hindered by many constraints, namely the low availability of feeds and particularly nitrogen-rich feeds in livestock compounded feeds. In fact, proteins constitute the main limiting factor in animal feeding, particularly in non-ruminants [2]. Shortage of proteins in a ration leads to a drop in animal performance $[3,4]$ and a feeding containing optimal quantities of proteins could improve animal performance [5-7]. Also, one way to improve animal feeding could consist of formulating quality rations, based on ingredients locally and easily available at a relatively affordable and profitable price. But, protein sources are scarce and when they exist, they are expensive. The valorization of new protein sources for livestock feeding, like flours from cockroaches, maggots, termites, earth worms, grasshoppers, etc., is therefore imperative as a possible alternative [8]. Among all these insects, maggot production is possible using a wide range of household wastes and agricultural by-products locally available [9]. Decaying organic matter can serve as substrates for maggot production) [8], and fresh or fermented wastes from animal origin attract flies on substrates [10]. Fly larvae have protein contents higher than 40\% [11]. Bouafou et al. [12] recorded protein contents between 47.50 and $52.23 \%$. So, Mensah et al. [13] and Malivel [11] believe that maggot flour could validly replace fish flour in non-ruminants' rations.

The global objective of this work was to determine best substrates for maggots' production. More specifically, this study was intended:

- To identify families of flies producing maggots.

To appreciate the production of maggots on different substrates.

*Correspondence to: Gilbert Comlan Zougou Tovignon, National Higher Institute of Agronomy and Biotechnology (INSAB), University of Science and Techniques Masuku (USTM), P.O. Box 941 Franceville, Gabon, Tel: 0024174336784; E-mail: zougou.g@gmail.com

Key words: Cow dung, rumen content, identification, fly larvae, production, bovine blood

Received: February 16, 2021; Accepted: March 08, 2021; Published: March 15, 2021 
- To characterize physically and chemically the maggots produced per substrate.

\section{Material and methods}

\section{Experimentation site}

The present study was carried out from February to June 2018 at the National Higher Institute of Agronomy and Biotechnology (INSAB) of the University of Science and Techniques, Masuku (USTM), located at Franceville in the Haut-Ogooué Province in Gabon. The area is located at a latitude of $1^{\circ} 37^{\prime} 59^{\prime \prime}$ south, a longitude of $13^{\circ} 35^{\prime} 00^{\prime \prime}$ and an altitude of $405 \mathrm{~m}$ above the sea level [14]. The climate is of equatorial type with two well-marked seasons (dry and rainy), with a mean annual temperature of $24.6^{\circ} \mathrm{C}$. The average rainfall is $1803 \mathrm{~mm} /$ year and the humidity fluctuates around $80 \%$ all year round [15].

\section{Origin of substrates}

The substrates used were made up of cow dung, rumen content (RC) and bovine blood. Fresh cow dung was collected at the INSAB stable and transferred in empty flour bags previously washed, rinsed, and dried. Freshly slaughtered bovine RC and blood were collected at the slaughterhouse of the Poto-poto market in Franceville. The blood was used as an attractive material for colonizing flies in substrates.

\section{Livestock management}

The completely randomized experimental design was constituted of 4 trials of 1,100 g each, repeated 3 times in plastic basins of $86 \mathrm{~cm}$ of diameter and $14 \mathrm{~cm}$ of height. The substrates were designed as follows:

$$
\begin{array}{ll}
\text { 口 } & \mathrm{S}_{1}=90.91 \% \text { of cow dung }+9.09 \% \text { of blood } \\
\square & \mathrm{S}_{2}=68.18 \% \text { of cow dung }+22.73 \% \text { of } \mathrm{RC}+9.09 \% \text { of blood } \\
\mathrm{B} & \mathrm{S}_{3}=45.45 \% \text { of cow dung }+45.46 \% \text { of RC }+9.09 \% \text { of blood } \\
\square & \mathrm{S}_{4}=22.73 \% \text { of cow dung }+68.18 \% \text { of RC }+9.09 \% \text { of blood }
\end{array}
$$

The breeding was conducted in semi-hard building, isolated, and sheltered from bad weather where flies could enter and leave freely. The entire experimental design was put in a $7.5 \mathrm{~m}^{2}$ box ( $3.0 \mathrm{~m}$ length $\mathrm{x} 2.5$ $\mathrm{m}$ width). The box was allowed open during 24 hours for colonization [16]; the basins that remained open to let the flies lay eggs on the substrates were then covered. The basins had small aeration holes made with the help of a nail. The daily follow-up of the trial was done three (03) times a day (at $8 \mathrm{AM}, 12 \mathrm{AM}$ and $5 \mathrm{PM}$ ). The basins were open during these periods of time for a better aeration of the culture media.

\section{Identification of families of flies}

For the identification of different colonizing flies in substrates, 63 flies were collected with the help of a cage covered with a mosquito net treated with a RAMBO brand insecticide. The cage contained plates in which small quantities of substrates (cow dung and RC) and blood were put. Once the flies were found in the cage, they were killed with the help of insecticide, then collected and conserved in alcohol at $70^{\circ}$. The collected flies were identified by observation of morphological characters with an OPTIKA brand binocular loupe at X2 magnification.

\section{Maggots harvesting}

The harvesting of flies larvae was done on the $5^{\text {th }}$ day after the beginning of the trial. The method used was the manual sorting. It consisted of soaking substrates in hot water at $60^{\circ} \mathrm{C}$ to kill the maggots found in it [17]. In fact, once the substrates were soaked, part of the killed larvae floated in hot water and picked with the help of a sieve, meanwhile the other part of larvae (dead and alive) were trapped inside the substrate. For the collection, 2 basins, one sieve, a plastic pot for each substrate and a filter were used. The trapped larvae were extracted gradually from small quantities of substrates. After the collection, the larvae were all transferred in 12 pots labeled according to different substrates.

\section{Bromatological analysis}

The analysis of samples of maggot flour were carried out at the Laboratory of Chemistry in the Faculty Science of the University of Science and Techniques, Masuku. The samples were used to determine chemical characteristics (in \%) (Water content, DM, CP, fats). Two repetitions were necessary to determine the mean value of each characteristic. The water content as well as the DM were determined using the methods described by AOAC [16]. The CP content was obtained using the Bradford method and the fat content using the extraction method with the help of the Soxhlet design [18].

\section{Productivity of substrates}

To determine the biomass of maggots produced, their fresh and dry weights were recorded according to substrates. After removing water from the pots, larvae were first of all exposed-on LOTUS paper during few minutes before recording fresh weight. Weighing was done using a digital TEFAL OPTISS brand balance (capacity $5 \mathrm{~kg}$ and precision $1 \mathrm{~g}$ ).

\section{Determination of measurements in larvae}

To determine the average length of a maggot in different substrates, ten (10) fresh maggots were randomly chosen and measured using a ruler.

\section{Determination of the dry weight of larvae}

After the fresh weight, the larvae were dried in an oven at $55^{\circ} \mathrm{C}$ for 24 hours. After cooling, the larvae were weighed again. For chemical analysis, the dry maggots were ground manually with the help of a bowl and conserved in numbered plastic sachets.

\section{Statistical analysis}

The data on biomass, measurements and chemical composition of maggot flour was submitted to the analysis on variance at one factor (substrate) following the general linear model (GLM). When the significant differences existed between treatments, the separation of means was done by the Waller-Duncan test at 5\% significant level [19]. The software used for the analysis was SPSS. 20.0.

\section{Results}

\section{Identification of families of flies involved in the colonization of substrates}

The Figure 1 illustrates the proportions of families of flies identified during the colonization of substrates.

From this figure, 4 families of flies were identified, namely Muscidae, Calliphoridae, Strationomiydae and Syrphidae. The most abundant family of flies was Calliphoridae (85.71\%). The other families were very less present.

\section{Mean biomass and measurements in maggots}

The biomass in fly larvae produced as well as their measurements according to substrate type were summarized in the Table 1. 
From the Table 1, both fresh and dry biomasses have not been significantly influenced by the nature of the substrate $(p>0.05)$. The mean height recorded with maggots from the substrate $\mathrm{S}_{1}$ was comparable $(\mathrm{p}>0.05)$ to that of maggots from the substrates $S_{2}(1.74$ $\pm 0.13 \mathrm{~cm})$ and $\mathrm{S}_{3}(1.82 \pm 0.06 \mathrm{~cm})$. In addition, the heights obtained with these substrates were significantly $(\mathrm{p}<0.05)$ higher than those of maggots from $\mathrm{S}_{4}(1.43 \pm 0.24 \mathrm{~cm})$.

\section{Chemical composition of maggot flour}

The chemical composition of maggot flour according to each substrate type is presented in the Table 2.

From this table, it shows that the nature of the substrate has not influenced significantly $(p>0.05)$ the variations in humidity and fat content. On the other hand, CP levels obtained from maggot flours in $\mathrm{S}_{3}$ and $\mathrm{S}_{4}$ were significantly higher than those obtained with maggot flours from $S_{2}(27.57 \pm 0.20 \%)$ and $S_{1}(26.56 \pm 0.32 \%)$ which were comparable $(\mathrm{p}>0.05)$ among them. It also turns out that the substrate type has significantly influenced $(\mathrm{p}<0.05)$ fat contents in maggot flours. In fact, highest fat content was obtained with maggot flour in $\mathrm{S}_{3}(24.87$ $\pm 0.36 \%)$ and the lowest value $(8.91 \pm 0.30 \%)$ with maggots in $S_{2}$.

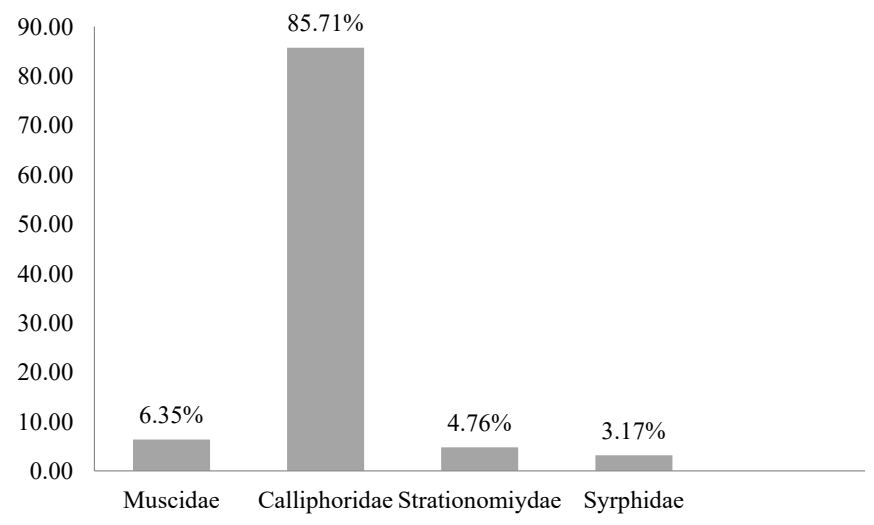

Figure 1. Proportion of flies identified according to families

Table 1. Mean biomass and measurements in maggots according to substrates

\begin{tabular}{|r|c|c|c|c|c|}
\hline \multirow{2}{*}{ Parameters } & \multicolumn{5}{|c|}{ Substrates } \\
\cline { 2 - 6 } & & $\mathbf{S}_{\mathbf{1}}$ & $\mathbf{S}_{\mathbf{2}}$ & $\mathbf{S}_{\mathbf{3}}$ & $\mathbf{S}_{\mathbf{4}}$ \\
\hline \multirow{2}{*}{ Biomass (g) } & Fresh (g) & $10.67 \pm 3.21^{\mathrm{a}}$ & $4.33 \pm 2.08^{\mathrm{a}}$ & $4.00 \pm 1.41^{\mathrm{a}}$ & $20.67 \pm 2.52^{\mathrm{a}}$ \\
\cline { 2 - 6 } & Dry (g) & $1.67 \pm 0.58^{\mathrm{a}}$ & $0.67 \pm 0.58^{\mathrm{a}}$ & $1.00 \pm 0.00^{\mathrm{a}}$ & $3.67 \pm 0.47^{\mathrm{a}}$ \\
\hline \multicolumn{2}{|r}{ Measurements (cm) } & $1.88 \pm 0.08^{\mathrm{b}}$ & $1.74 \pm 0.13^{\mathrm{b}}$ & $1.82 \pm 0.06^{\mathrm{b}}$ & $1.43 \pm 0.24^{\mathrm{a}}$ \\
\hline
\end{tabular}

a, $b$ : Means bearing the same letters on the same line are comparable at $5 \%$ significant level.

Table 2. Chemical composition of maggots according to substrates

\begin{tabular}{|c|c|c|c|c|}
\hline \multirow{2}{*}{ Parameters } & \multicolumn{4}{|c|}{ Substrates } \\
\cline { 2 - 5 } & $\mathbf{S}_{\mathbf{1}}$ & $\mathbf{S}_{\mathbf{2}}$ & $\mathbf{S}_{\mathbf{3}}$ & $\mathbf{S}_{\mathbf{4}}$ \\
\hline Humidity (\%) & $81.34 \pm 10.41^{\mathrm{a}}$ & $72.39 \pm 21.62^{\mathrm{a}}$ & $78.57 \pm 0.77^{\mathrm{a}}$ & $82.75 \pm 2.48^{\mathrm{a}}$ \\
\hline DM (\%) & $18.66 \pm 10.41^{\mathrm{a}}$ & $27.61 \pm 21.62^{\mathrm{a}}$ & $21.43 \pm 1.08^{\mathrm{a}}$ & $17.25 \pm 2.48^{\mathrm{a}}$ \\
\hline CP(\%) & $26.56 \pm 0.32^{\mathrm{a}}$ & $27.57 \pm 0.20^{\mathrm{a}}$ & $34.66 \pm 0.10^{\mathrm{b}}$ & $35.98 \pm 2.21^{\mathrm{b}}$ \\
\hline Fats (\%) & $11.35 \pm 0.43^{\mathrm{b}}$ & $8.91 \pm 0.30^{\mathrm{a}}$ & $24.87 \pm 0.36^{\mathrm{d}}$ & $14.38 \pm 0.76^{\mathrm{c}}$ \\
\hline
\end{tabular}

a, b, c, d: Means bearing the same letters on the same line are comparable at $5 \%$ significant level.

\section{Discussion}

The family Calliphoridae was the most represented with $85.71 \%$ of identified individuals. The same observation was made by Bouafou et al. [15] during a study conducted on the inventory of flies on various by-products in Ivory Coast. The marked presence of this family could be justified by its height, its social and cosmopolitan character. In fact, according to Byrd and Castner [19], this family has more than 1000 species and members can be found worldwide. Claude and Daniel [20] also affirm that Calliphoridae like flying in groups and once a fly detects an excrement on which it can lay, it releases pheromones to alert the other individuals. They then come massively and colonize the substrate first. In addition, according to Bouafou et al. [15] and Keiding [10] garbage is mostly visited by Calliphoridae. The Muscidae was the second most represented family $(6.35 \%)$. The low abundance of Syrphidae (3.17\%) could be linked to the scarcity of flowers on the site because, adults from this family live on flowers [21].

The highest quantity of fresh biomass in maggots in this study $\left(20.67 \pm 25.15 \mathrm{~g}\right.$ in $\left.\mathrm{S}_{4}\right)$ was greater than the one obtained by Ndadi [22], with the bovine rumen content (10.05 g) and by Kéyi [23] with the fowl droppings. But this quantity was lower than that obtained by Tendonkeng et al. [24] (66.10 g) with the rumen content containing blood. This difference could be linked to the chemical composition of substrates, or the nutritional content of the substrates [25]. Tendonkeng et al. [24] mentioned that the addition of fresh bovine blood in the substrates improves the biomass of maggots produced. On the other hand, the substrate $S_{3}$ was revealed less productive $(4.00 \pm 1.41 \mathrm{~g})$. This low biomass obtained could be explained by the fact that, the attractiveness of cow dung and rumen content coupled with the addition of blood could lead to an increase in the number of flies on substrate caused by an increase in the number of eggs laid and the number of maggots, hence reducing the nutrients in the substrates. Many larvae die, those surviving do not develop well due to a shortage of nutrients in the substrate. In fact, according to Keiding [10], dairy products as well as fresh or fermented wastes from animal origin (different types of meat, excrements, blood etc.) attract flies that come massively to lay.

On the other hand, the level of attractiveness of substrates and the available nutrient content could equally justify the results in measurements. It is observed that the highest length $(1.88 \pm 0.08$ $\mathrm{cm}$ ) was obtained with maggots from the substrate $S_{1}$. This value was comparable to that obtained by Tendonkeng et al. [24] $(1.22 \mathrm{~cm})$; this relatively good height could be explained by the nutritional content of the substrate and consequently permits the increase in maggots height with time $[15,26,27]$. The cow dung and the blood being more attractive, the quantity of eggs laid and the number of hatched eggs proportional to the nutrient content, could justify the good development of larvae in the substrate. The lowest mean length $(1.43 \pm 0.24 \mathrm{~cm})$ was recorded in the substrate $\mathrm{S}_{4}$; this value is like the norm indicated by Bouafou et al. [28] and Kéyi [23], which is 0.4 to $1.5 \mathrm{~cm}$ according to their age in days.

The highest humidity rate $(82.75 \pm 2.48 \%)$ from maggots in the substrate $\mathrm{S}_{4}$, was comparable $(\mathrm{p}>0.05)$ to that from maggots in substrates $\mathrm{S}_{3}(87.57 \pm 0.77 \%), \mathrm{S}_{2}(72.39 \pm 21.62 \%)$ and $\mathrm{S}_{1}(81.34 \pm 10.41 \%)$. All these values were lower than that obtained by Bouafou et al. [12] (92.51\%); this difference could be justified by the quantity of water present in these substrates. On the other hand, this value of $82.75 \pm$ 
$2.48 \%$, obtained with maggots from $\mathrm{S}_{4}$, is close to the one obtained by Keyi [23] who recorded a water content of $87.47 \pm 4.49 \%$ with maggots in substrate containing swine dung plus blood. The highest DM content $(27.61 \pm 21.62 \%)$ was obtained with maggot flour from the substrate $\mathrm{S}_{2}$ and the lowest DM content $(17.25 \pm 2.48 \%)$ was obtained in flour from the substrate $\mathrm{S}_{4}$. It appears from all these values that the DM content is inversely proportional to the humidity rate.

The highest CP level $(35.98 \pm 2.21 \%)$ was obtained with maggot flour in the substrate $S_{4}$; it was comparable $(p>0.05)$ to that of the maggot flour from the substrate $\mathrm{S}_{3}(34.66 \pm 1.10 \%)$. These values were lower than those recorded by Sogbessan et al. [27]; Bouafou et al. [12] and Bouafou et al. [28], respectively comprised between 47.50 and $54.00 \% ; 52.23 \%$ and $50.17 \%$, equally lower than those obtained by Tendonkeng et al. [24] and Keyi [23], respectively $53.10 \%$ and $57.14 \%$. The fat contents of the maggot flour were significantly different $(\mathrm{p}<0.05)$ in all the substrates. The lowest value $(8.91 \pm 0.30 \%)$ was recorded with maggot flour in $\mathrm{S}_{2}$. This value was lower than those obtained by Nzamujo [29], Sogbessan et al. [27], Bouafou et al. [12] and Bouafou et al. [28], respectively $19.30 \% ; 19.30 \% ; 24.43 \%$ and $35.41 \%$. Concerning the $\mathrm{CP}$ and fats contents, difference in results could be justified not only by the nutrients available in different substrates but also by the developmental stages of larvae. In fact, Ekoue and Hadzi [26] and Bouafou [28] mentioned that the chemical composition of maggot flour could depend on the larval developmental stage $[29,30]$. So, the most interesting stage is the one of maggot but the closest stage of its transformation into pupa to benefit from all the nutrients (proteins, fats and minerals) $[7,31,32]$.

\section{Conclusion}

At the end of this study, it appears that 4 families of flies (Muscidae, Calliphoridae, Strationomiydae and Syrphidae) were identified. The most represented among them was the Calliphoridae. Apart from biomass values, humidity and DM content, substitution has influenced the measurements, the $\mathrm{CP}$ and fats contents. Regarding all these results obtained, the substrate $\mathrm{S}_{4}$ made up of $250 \mathrm{~g}$ cow dung, $750 \mathrm{~g}$ of rumen content and $100 \mathrm{~g}$ of blood can be recommended for maggot production in non-ruminants' feeding.

\section{References}

1. Direction Générale de la Statistique - Gabon (2011) Annuaire statistique du Gabon-2005-2009. $13^{\text {ème }}$ édition.

2. Kondombo SR, Kwakkel RP, Nianogo AJ, Slingerland M (2003) Effects of local feedstuff supplementation on zootechnic performances and nutritional status of village chickens during the end of the rainy season in Burkina Faso. Revue d'Elev Méd Vét Pays Trop 56: 3-4.

3. Boucher S (1995) Alimentation des lagomorphes et rongeurs de compagnie: Quelques données de base. In : CNVSPA (eds.). Congrès annuel: Conduite diagnostique et thérapeutique: Actualités. Paris, 24 : 151-160.

4. Rosse L (1999) Alimentation des rongeurs et lagomorphes de compagnie. Médecine Vétérinaire Alfort: 1999: 10.

5. Noumbissi MNB, Tendonkeng F, Zougou TG, Pamo TE (2014) Effet de différents niveaux de supplémentation de feuilles de Tithonia diversifolia (Hemsl) A Gray sur l'ingestion de la digestibilité in vivo de Pennisetum purpureum K. Schum. Chez le cobaye (CaviaporcellusL.). Tropicultura 32: 3138-146.

6. Miégoué E (2016) Trois légumineuses fourragères (Arachis glabrata, Calliandra calothyrsus ou Desmodium intortum) comme source de protéines associées à deux graminées (Pennisetum purpureum et Panicum maximum) dans l'alimentation des cochons d'inde (Cavia porcellus $\mathrm{L}$.). Thèse de Doctorat $(\mathrm{PhD})$ en Biotechnologie et Productions Animales. Université de Dschang: 158.

7. Zougou TCG (2017) Besoins protéiques et performances de production du cobaye (Cavia porcellus $\mathrm{L}$.) à l'Ouest Cameroun. Thèse de Doctorat $(\mathrm{PhD})$ en Biotechnologie et Productions Animales. Université de Dschang: 183.
8. Hardouin J, Dongmo T, Ekoue SK, Loa C, Malekani M, Malukisa M (2000) Guide technique d'élevage $\mathrm{N}^{\circ} 7$ sur les asticots [On line]. Bureau pour l'échange et la distribution de l'information sur le mini-élevage (B.E.D.I.M.), éd. J. Hardouin, BEDIM: 8 .

9. Burton M, Burton R (1973) Grand dictionnaire des animaux, tome 16, Bordas, EditoSce S.A. Genève, $196 \mathrm{p}$.

10. Keiding J (1986) La mouche domestique. Guide de formation et d'information, Série lutte anti-vectorielle. Ed. OMS : 60.

11. Malivel A (2014) Le mini-élevage des asticots ou la « larviculture », Rédigé pour les élèves et les responsables du centre Songhaï de Porto-Novo.

12. Bouafou KGM, Kouame KG, Offoumou AM (2007) Bilan azoté chez le rat en croissance de la farine d'asticots séchés. Tropicultura 25: 70-74.

13. Mensah GA, Pomalegni SCB, Koudjou AL, Cakpovi JCG, Adjahoutonon KYKB, Agoundo A (2007) Farine d'asticots de mouche, une source de protéines bien valorisée dans l'alimentation des canards de barbarie, Communication au 1er Colloque de l'UAC des Sciences et Cultures à Abomey-Calavi (Bénin) du 24 au 29/06/2007. Atelier III: Sciences Naturelles et Agronomiques.

14. FDNS (2004) Information for MSKU as of August 2004.

15. Bouafou KGM, Kouamé KG, Amoikon EK, Offoumou AM (2006) Potentiels pour la production d'asticots sur des sous-produits en Côte d'Ivoire. Tropicultura 24 : 157-161.

16. AOAC (Association of Official Analytical Chemist) (1990) Official method of analysis $15^{\text {th }}$ edition. AOAC. Washington D.C: 10 .

17. Bradford M (1976) A rapid and sensitive method for the quantization of microgram quantities of protein utilizing the principle of protein-dye binding. Analytical Biochemistry 72: 248-254.

18. Steel RG, Torrie JH (1980) Principles and procedures of statistics. $2^{\text {nd }}$ edition M.C Graw hill Publishing Company, New-York: 633.

19. Byrd JH, Castner JL (2010) Insects of forensic importance. In Forensic entomology: the utility of using arthropods in legal investigations (ed. by J.H. Castner \& J.L. Byrd), CRC Boca Second Edition, Raton, FL: 29-126.

20. Claude Wyss, Daniel Cherix (2013) Traité d'entomologie forenstine : les insectes sur la scène de crime. Concrete tanks. World J Agricul Sci 4: 394-402.

21. Dussaix C (2009) Diptères Syrphidae, ed. INSECTES DIPTERES in Invertébrés continentaux au pays de la Loire - Greta.

22. Ndadi NK (2010) Contribution à l'étude des substrats adéquats pour la production d'asticot comme aliment pour volaille à Kinshasa, TFE en Zootechnie, Faculté des Sciences Agronomiques/Unikin, 25p.

23. Keyi RP (2014) Evaluation comparative de la production et de la valeur nutritive des asticots produits dans les fientes de poule et le lisier de porc 2: 10-11.

24. Tendonkeng F, Miégoué E, Lemoufouet J, Mouchili M, Matimuini NF, et al. (2015) Production et composition chimique des asticots en fonction du type de substrat. Livestock Res Rural Develop 29: 2017.

25. Wigglesworth VB (1970) La vie des insectes. Ed. Bordas, Paris, France: 383

26. Ekoue SE, Hadzi YA (2000) Production d'asticots comme source de protéines pour jeunes volailles au Togo. Observations préliminaires. Tropicultura 18: 212-214.

27. Sogbessan AO, Ajuonu N, Musa BO, Adewole AM (2006) Harvesting techniques and evaluation of maggot meal as animal dietary protein source for heteoclarias in outdoor.

28. Bouafou KGM, Zannou-Tchoko V, Konan BA, Kouame KG (2008) Etude de la valeur nutritionnelle de la farine d'asticots séchés chez le rat en croissance. Revue Ivoirienne des Sciences et Technologie 12: 215-225.

29. Nzamujo OP (1999) Techniques of maggot production-the Songhai Experience. Unpublished.

30. FAO (2005) Importation des produits de base au Gabon.

31. Hardouin J (1986) Mini-Elévage et sources méconnues de protéines animales. Annales de Gembloux, 92: 153-162.

32. Hardouin J, Mahoux G (2003) Elevage et utilisation au bénéfice de l'homme et de certains animaux. Bureau pour l'échange et la distribution de l'information sur le miniélevage (BEDIM). Gembloux 30: 83-93.

Copyright: (C2021 Tovignon GCZ. This is an open-access article distributed under the terms of the Creative Commons Attribution License, which permits unrestricted use, distribution, and reproduction in any medium, provided the original author and source are credited. 